\title{
A Study on Classroom Teaching Style and Learning Outcome
}

\author{
Zhang $\mathrm{Xu}^{1 *}$ \\ ${ }^{1}$ Foreign Language Department, Beijing Institute of Petrochemical Technology, Beijing, China \\ *Zhang Xu, E-mail: zhangxuwy@bipt.edu.cn
}

\begin{abstract}
Teaching style is the reflection of individualism in the art of teaching. All excellent teachers unfold before the students their unique teaching methods, teaching techniques and teaching beliefs which result in effective learning outcome. This paper is based on a course which I audit during my visiting in the US. Through the observation of classroom lecture, analysis of after-class notes and interviews with the teacher' a comparative study of classroom teaching style between Chinese and American teachers is conducted as well as the possible factors behind it. The findings of the paper will positively promote the creativity and innovation of the Chinese College English teachers who will make a reflection on their own teaching and make every effort to formulate their own teaching style in order to achieve a higher standard of college English teaching and at the same time promote college English learning.
\end{abstract}

\section{Keywords}

teaching style, teaching methods and beliefs, learning outcome

\section{Introduction}

Education is always attached importance to since ancient China. However, with the development of science and technology, especially with the open door policy, Chinese teachers as well as the students have come to realize that education means more than mere knowledge input, they are pondering on the best way to teach and to learn more effectively both in and outside the classroom.

Teaching style, which is considered the unique method, the techniques and the ideals of a teacher, plays an important role in foreign language teaching. It is influenced by many factors including culture, education policy, teaching contents or students' ability to learn, and it is one of the key points that determine the learning efficiency. As is said by the famous educator and educational theorist in former Soviet Union Wa A Sukhomlinsky, what we believe to be education is the recreation of oneself in another (Wa, 1981, 1983). Even though there are unified teaching goals and teaching principles, teaching is unique activity of each individual teacher, it is really different when they choose different methods and procedures in real teaching, thus the study of teaching style is important and meaningful as well.

In October 2012, I came to the US as a visiting scholar. This gives me a good chance to make a close observation of the teaching style of an American teacher and therefore I can make a comparative study of the differences and similarities of the teaching styles between Chinese teachers and American 
teachers and consequently the findings will be of great help to my teaching back home.

The course which I audit in English Department is "An introduction to the principles of artistic expressiveness of films; lighting, color, camera, composition, space, movement, image, setting and sound" (Wa, 1983). And the "narrative techniques and editing styles" (Lessard, 2012) are also discussed in class. Both American and foreign films are viewed and discussed in which theories as realism, formalism, surrealism, Marxism, psychoanalysis and gender theory are explored (Lessard, 2012). The class meets four periods a week, with one period for screening the film which will be discussed in the week and the other three periods are the time for lecture. Films of different genre are viewed including feature stories, science fiction, musicals and documentaries.

Research method of this paper is biographic inquiry and the classroom observation combined with after class notes and interviews provides me with a rich background material to make a detailed analysis of the differences and similarities of the teaching style between Chinese and American teachers. The possible factors can be an enlightenment to improve college English teaching in China.

\section{Classroom Observation}

\subsection{Screening}

Fourteen films are shown for the whole semester. The weekly screening "will demonstrate critical terms and concepts in context, as well as introduce historically significant films that demonstrate the aesthetic vitality, range, and cultural importance of moving images" (Lessard, 2012). And students are required to hand in their screening notes every week.

\subsection{Lecture}

Lecture time is one hour forty five minutes every Monday, Wednesday and Friday. The teacher usually begins his class with questions and concepts that related to the film for the week. During the whole class, he keeps on presenting knowledge in cinematography. And the best part of it is he could always explain those terms thoroughly and fluently by showing some of the clips of the targeted film, therefore, his lecture is very informative. Students are allowed to ask questions whenever they don't understand or when they feel like asking questions. And during the time, the teacher is always very patient to answer those questions first and then goes on with his topic.

There are three things that impress me most in class. First the teacher has a good command of knowledge on film analysis and he is capable of making the class more interesting by citing the well-prepared related films clips, images and music to assist understanding of the principles, techniques and styles whenever he tries to explain them for a certain film. Second, the teaching procedure in class is closely related to one another and a fast and logical rhythm of teaching is created. He controls the rhythm well and never delays the class when it should be over. And the classroom atmosphere is lively and active and harmonious. The teacher is a good language manipulator and he is very competent in the interaction with the students in class. The way questions asked and answered serve as a good means of enlightening students' ideas and expressing how they feel about the film. Third, the teacher's personal 
character leaves me with a good impression. He is very nice and kind and amiable and gentlemanlike in class. Always in checked shirt, he would like to get closer to the students when he asks and answers the questions. He is open-minded in introducing both American and foreign films in class and also invites two cinematographers, one from Haiti and the other from China, to present their films from different cultural background. All in all, effectiveness and efficiency are the key factors of his teaching in class.

\subsection{Evaluation}

There are three midterm examinations respectively held in September, October and November and there is the final examination held in December. The first midterm accounts for $15 \%$ and the next two midterm accounts for $20 \%$ each and with the final exam accounts for $30 \%$. The screening notes every week and class participation also account for $15 \%$.

Unlike that in China where we have only one midterm examination, the three midterms just remind the students of their period study and enhance their reflection on their study during a month. This is a good way to encourage the students in their learning during the whole term.

\subsection{Modern Technology}

The teacher applies modern technology in his class in two ways, one is the teaching materials presented in class and the other is the online learning system. In class he presented PDF files and PPT to illustrate the principles, techniques and styles reflected in a certain film. And his PPT just highlights the key terms for the students which is clear and to the point.

The teacher uses the school online learning system to provide reading materials, film clips and teaching resources. Announcements are often made to remind the students of their homework, reading materials, films to watch and the coming of the exams. In this way students are constantly called attention to the fact that they have good preparation for the class. Even the midterm exams are conducted online and students are able to learn about their evaluations soon after the exam.

By applying the modern technology, not only an effective and efficient way of teaching is achieved but also a closer relationship is established between the students and the teacher since they are able to communicate with each other through Internet, therefore, learning happens whenever and wherever possible.

\section{Analysis of Teaching Style}

\subsection{Teaching Beliefs}

The teacher of the course has been teaching English Film, literature and writing classes for more than 10 years. For him "the world is a very complicated work of art and it is full of images, words and information for us to understand with critical eye" (interview). He believes it is his mission to "help students closely attend to the world around them, to see the world itself as a very complicated work of art" (interview). He believes the students are vibrant and creative individuals and therefore he hopes to provide them with "the intellectual tools and critical frameworks that will empower them and give them earned confidence in their own intellects and imagination" (interview). While in contrast I used to 
believe teaching is to "transmit wisdom, impart knowledge and solve doubts" (Han Yu, Tang Dynasty). It is my job to provide the students with the knowledge they are to learn in class and through accumulation of what they learn in class they are able to see the world by themselves. Thus we could see American teacher's value inspiration of students' imagination and critical thinking in their studies while Chinese teachers' beliefs have changed through times from "teacher-centered transmission of knowledge from generation to generation" to "student-centered critical thinking in what they learn".

\subsection{Teaching Techniques and Methods}

The teacher of the course in class is student-centered and task-based. For each class he has a clear and logical organization of the teaching materials as assigned to the students before class, during the time in class, he would like to explain to the students those terms, techniques and editing styles in the film. He keeps on encouraging the students to ask questions and express how they feel about the film. Sometimes when he was just explaining a certain concept or filming techniques, he would stop immediately to allow the students to ask questions if they don't understand. And through the discussion and inspiration, learning is going on smoothly in class.

And there is one film shown each week, so all the discussions just focus on the film and all the reading materials after class also center around cinematography reflected in the film for the week. Thus, students are clear in mind what they are going to talk about in class and what they are going to learn in class.

A Chinese teacher likes to prepare his teaching well before class. They are careful about different teaching procedures in class such as lead-in, background knowledge, and detailed study and after reading. The lead-in and background knowledge aim to inspire students' interests for the lesson and detailed study of the text serve as accumulation of knowledge for the students. And after-reading is a time to review what they have learned previously and what they are going to read after class. For the whole term Chinese teachers will assign extra reading materials or recitations of the selected paragraph from the text.

American teachers and Chinese teachers are the same in student-centered method and task-based principle. But one difference lies in the classroom where American teachers like to discuss more with the students and allow the students to express their thoughts whatever they are while Chinese teachers tend to believe "more teaching" in class and complete what they have assigned for the students without leaving much time for students to participate in classroom discussion. It seems a common belief in China that if a teacher don't "teach" (imparting knowledge) in class, then how can a student learn?

\subsection{Teaching Facilities}

With the development of modern technology and the Internet, it is very convenient for teachers to conduct lessons in class in a vivid way. PDF files, PPT and online resources are available for the convenience of the students. Even the exams are held through online learning system. It is platform for the teachers to make announcements about the homework and the reading assignments and the examinations. And students are able to make a response whenever and wherever they are. 
The convenient modern techniques in teaching just makes the unique teaching styles of both the American and the Chinese teachers and provide a great aid for their teaching in class since everything is prepared well before each class.

\subsection{Personal Character}

Individual personality is an important composition of teaching styles and it is vital in teaching. The teacher of the class which I audit is watching the film clips and reading materials after class. With a comprehensive knowledge of film analysis, his lecture is inspiring and informative, providing a systematic guidance for the students to analyze the film they have seen.

There could be personal differences in the teachers' character either in America or in China, some are kind while others are strict, there is the universal truth for the teacher that "being a language master and quick in mind and exact in explanation" (Ye, 2001). Those who are competent to create a harmonious relationship with the students in and after class are greatly welcome and their efforts produce best learning results.

\section{Conclusions}

Teaching styles are different from others in their uniqueness and stability. The reason why a certain teacher chooses one style rather than the other is dependent on his own personal character, his teaching beliefs and teaching facilities. Also teaching policy and teaching reform play an important role in the formation of the teaching styles. By making a comparison of the differences and similarities of the teaching styles, this paper aims at the following suggestions.

\subsection{Teaching Belief}

College English teachers must bear in mind the fact that teaching is a way to inspire, to facilitate and to help students to see the world around him in their own eyes. Therefore student-oriented method should be of top priority in teaching. No matter who you are teaching, what materials you are teaching, what modern techniques you are applying, the most important thing for a college English teacher to do in class is to inspire independent and critical thinking of what they are learning. Teaching is not lecture without discussion.

\subsection{Teaching Preparation}

Nowadays in our college teaching classroom, we present the students with PPT full of information adapted just from the text book or visual pictures or videos to make learning easier. And teachers are making their efforts to prepare questions, to get students involved in classroom discussion. But on a whole, what the teacher believes to be important for the students to learn is not understood by the students and their mutual needs seem to be on different tracks. What I believe here is teachers should target their preparation of each class for the interests and needs of the students and learn more about students' thinking about the lesson. Therefore, target preparation can produce excellent learning result either in or after class.

\subsection{Teaching Policy}

Published by SCHOLINK INC. 
Teachers are able to focus on their teaching and love their work if under good teaching policy. Nowadays in China, education reform is on the way and college English teaching reform is also achieving good results in the universities around the country. It is better for school authority to provide the teachers with convenient teaching facilities, harmonious teaching environment and reasonable teacher evaluation system, then teachers can devote themselves to their teaching.

In conclusion, teaching style plays an important role in education and only with the development of teachers there is the development of education, thus the development of the students learning.

\section{References}

He, X. W. (2006). A Case Study on the Formation of Teaching Style. Master's Thesis in Zhejiang Normal University.

Lessard, J. (2012). Syllabus and Calenda. English Dept.

Liu, J. S., \& Li, Z. H. (2011, May). The Exploration of English Education within the Context of Globalization. Journal of Jishou University(Social Science Education).

Opdenakker, M. C., \& Van, D. J. (2006). Teacher characteristics and teaching styles as effectiveness enhancing factors of classroom. Teaching and Teacher Education, 22(1), 101-121.

Richard, M. F., \& Eunice, R. H. (2008). Learning and Teaching Styles In Foreign and Second Language Education. Foreign Language Annals, 28(1), 21-31.

Wa, A. S. (1981). One Hundred Suggestions to Teachers. Publishing House of Education and Science Beijing.

Wa, A. S. (1983). Art of Education. Publishing House of Hunan Education.

Ye, L. (2001). On the Study of Teacher Role and Teacher Development. Publishing House of Education and Science. 